\title{
Tall stature due to Beckwith Wiedemann Syndrome
}

Dharshini Karuppiah, Mithusha Markandu

Endocrine unit, Teaching Hospital Batticaloa, Sri Lanka

\section{Abstract}

Tall stature is less commonly referred to specialist care. Familial, nutritional and hormonal causes are mainly encountered. Beckwith Wiedemann Syndrome (BWS) is a rare congenital disease, referred as an overgrowth syndrome. Affected children tend to be taller than their peers during childhood. Children with BWS are at increased risk of childhood cancer, regular screening will prompt for better outcome. We present a 7 year-old girl child with BWS referred for evaluation of tall stature.

Key words: Tall stature, Beckwith Wiedemann Syndrome, childhood cancers

\section{Introduction}

Tall stature is defined as a height of more than 2 standard deviations above the corresponding mean height for age and sex as observed in the population. Compared to children with short stature, tall stature is a less commonly referred from primary health care to specialist care. Familial and nutritional tall stature are the common causes. Hormonal causes such as growth hormone excess, precocious puberty and hyperthyroidism are the next important pathologies to be excluded. Children with Homocystinuria, Marfan syndrome and Klinefelter's syndrome $(46, \mathrm{XXY})$ also can present with tall stature. Beckwith Wiedemann Syndrome (BWS) is a rare congenital disease. This condition is referred as an overgrowth syndrome, which means that affected infants are considerably larger than normal (macrosomia) and tend to be taller than their peers during childhood. Growth begins to slow by about age 8 , and adults with this condition are not unusually tall. We present a girl child with BWS referred for evaluation of tall stature.

\section{Case Presentation}

\begin{abstract}
Seven years old girl was referred to Endocrinology unit, Teaching Hospital Batticaloa for further evaluation of tall stature. The child was a product of consanguineous marriage. The mother was 40 years old at the time of delivery, but had an uneventful perinatal period with birth weight of $2.18 \mathrm{~kg}$. She reached development milestones age appropriately except mild impairment in social, emotional and behavioural development. At the age of 18 months, the child was referred for abdominal distension and dysmorphic features when she admitted with chest infection. But the parents defaulted further follow-up.
\end{abstract}

On examination her weight was $28 \mathrm{~kg}$; between $75^{\text {th }}$ to $90^{\text {th }}$ centile in the CDC (centres for disease control and prevention) chart and her height was $134 \mathrm{~cm}$; more than $97^{\text {th }}$ centile. She had number of dysmorphic features including triangular shaped face with pointed chin, high arch palate, macroglossia, and ear lobes with single creases. She also had dark valvety pigmentation suggestive of acanthosis nigricans in neck, armpits and elbow region. In addition, there was hemi hypertrophy affecting the right side and mild scoliosis. She had distended abdomen, moderate hepato-spelenomegaly and umbilical hernia (figure 1, 2 and 3; Parants' informed consent and permission to use these

Received: 23rd May 2018

Accepted with revision: $2^{\text {nd }}$ June 2018

Published: $31^{\text {st }}$ Aug 2018

Correspondence email: kdharshinik@gmail.com

D https://orcid.org/0000-0003-3546-8685

This is an open-access article distributed under the terms of the Creative Commons Attribution License, which permits unrestricted use, distribution, and reproduction in any medium, provided the original author and source are credited (CC BY 4.0) 
views was granted in accordance with recognized guidelines on the ethics of such photography). External genitalia looked normal female with pubic hair tanner stage 1 . Her breast development was at tanner 2 stage.

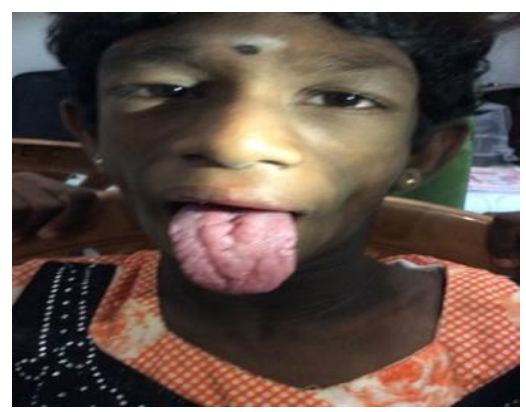

Figure 1: Macroglossia in a child with BWS

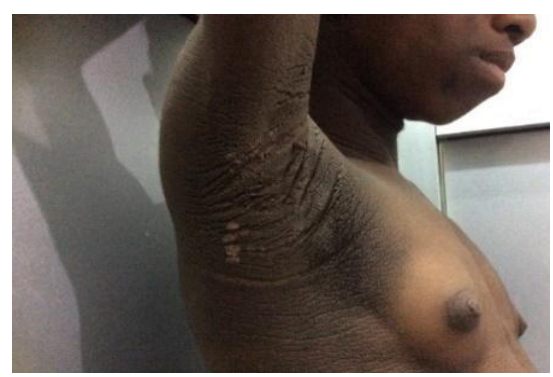

Figure 3: Acanthosis nigricans affecting neck and armpit in a child with BWS
She had advanced bone age of 11 years. She had normal hormonal profile. Biochemical investigations revealed high ALT (table 1). Moderate hepatomegaly with mild splenomegaly was evident on sonography, but both kidneys were normal as well as cardiac imaging.

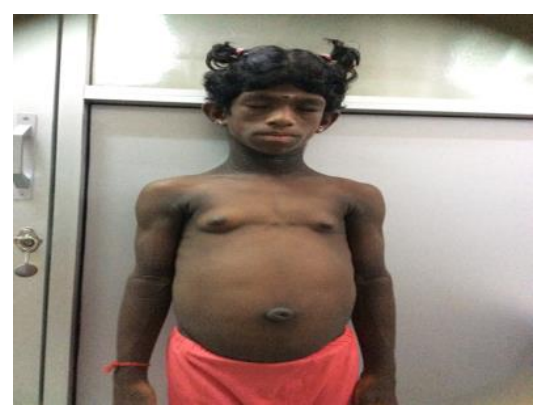

Figure 2: Umbilical Hernia and Right hemi hyperplasia in a child with BWS

\section{Table 1: Hormonal and biochemical investigations of a child with BWS}

$\begin{array}{lll}\text { Test } & \text { Results } & \text { Reference value } \\ \text { IGF-I }(\mu \mathrm{g} / \mathrm{l}) & 98.67 & 30-342 \\ \text { Growth Hormone }(\mathrm{ng} / \mathrm{ml}) & 0.13 & 2-5 \\ \text { TSH }(\mathrm{uIU} / \mathrm{ml}) & 1.94 & 0.3-4.20 \\ \text { Free T4 }(\mathrm{ng} / \mathrm{dl}) & 1.60 & 0.9-1.70 \\ \text { Free T3 (pg/ml) } & 3.6 & 2.0-4.4 \\ \text { FSH }(\mathrm{IU} / \mathrm{L}) & 1 & <0.1-4 \\ \mathrm{LH}(\mathrm{IU} / \mathrm{L}) & 0.5 & <0.1-5 \\ \text { FBS }(\mathrm{mg} / \mathrm{dl}) & 70 & 70-100 \\ \text { PPBS }(\mathrm{mg} / \mathrm{dl}) & 98 & <140 \\ \text { S.Creatinine }(\mathrm{mg} / \mathrm{dl}) & 0.3 & 0.6-1.2 \\ \text { Na }(\mathrm{mmol} / \mathrm{l}) & 135 & 135-148 \\ \mathrm{~K}^{+}(\mathrm{mmol} / \mathrm{l}) & 4.5 & 3.5-5.3 \\ \text { ALT }(\mathrm{IU} / \mathrm{L}) & 120 & 7-35 \\ \text { Serum Ca }(\mathrm{mg} / \mathrm{dl}) & 9.7 & 8.5-10.5 \\ \text { Phosphorus }(\mathrm{mg} / \mathrm{dl}) & 4.9 & 2.5-4.5 \\ \text { Urinary calcium:creatinine }_{\text {Serum Alpha feto protein }(\mathrm{ng} / \mathrm{dl})} & 0.08 & <0.14\end{array}$

FBS-fasting blood glucose, PPBS-post prandial blood glucose 


\section{Discussion}

BWS has its apparent origin in an alteration of the expression of genes from chromosome 11 region p15.5, which can be sporadic $(85 \%)$, inherited $(15 \%)$ or because of chromosomal abnormalities (1\%) (1). BWS should be considered a clinical spectrum, with some affected individuals having only one or two suggestive clinical findings.

The following clinical criteria could be taken as a guide to diagnosis, but cannot substitute for clinical judgment. The diagnosis of BWS is established in a child with 3 major or two major plus at least one minor criteria or by genetic testing (an epigenetic or genomic alteration leading to abnormal methylation at $11 \mathrm{p} 15.5$ or a heterozygous BWScausing pathogenic variant in CDKN1C) in the presence of one or more clinical findings (Table 2) (2). Our patient fulfilled 6 major and 1 minor criteria for the diagnosis of BWS.

Management of children with BWS depends on clinical presentation. They may require surgical correction of umbilical hernia, cleft palate etc. Children with BWS are at an increased risk of developing several types of tumors, particularly Wilms tumor and hepatoblastoma. Tumors develop in about 10 percent of people with this condition and almost always appear in childhood. Their life expectancy is usually normal unless they develop cancer. Therefor screening with abdominal sonography, 3 monthly till 8 years of age and yearly thereafter; monitoring serum alpha-feto-protein 3 monthly till 4 years of age is recommended (3). Annual or biannual measurement of urinary calcium: creatinine ratio will aid early diagnosis of nephrocalcinosis or medullary sponge kidney disease. Since the natural history of renal disease in adults has not as yet been evaluated, adult-onset renal disease without early findings remains a possibility. Therefore, consideration should be given to periodic renal evaluation in adulthood. (4)

Our patient had hepatomegaly with elevated ALT, but alpha-feto-protein was within normal range. Acanthosis nigricans is not a feature of BWS. This girl had severe acanthosis but normal fasting and post prandial glucose values. She needs regular screening.

\section{Conclusion}

BWS is rare and phenotypic variability is more. As children with BWS are at increased risk of childhood cancer, regular screening will prompt for better outcome.

Table 2: Clinical criteria used for diagnosis of BWS

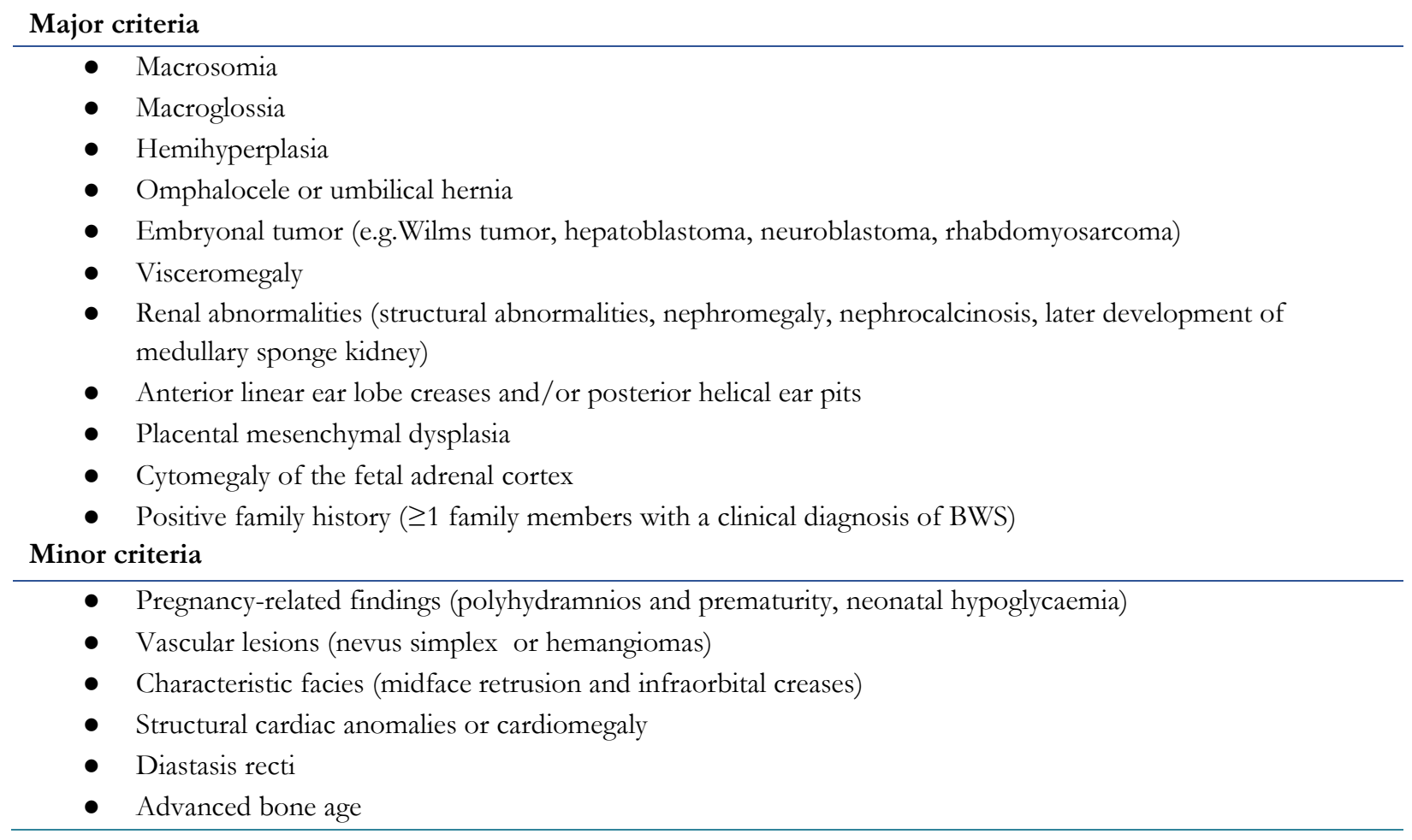


1. Li M. Molecular Genetics of Wiedemann Beckwith Syndrome (BWS) a case report and literature review. Am J Med Gen. 1998 Oct $2 ;$ 79(4): 253-9.

2. Shuman C, Beckwith JB, Weksberg R. Beckwith-Wiedemann Syndrome. GeneReviews 2000 Mar 3 [Updated 2016 Aug 11]. https://www.ncbi.nlm.nih.gov/books/NBK1394/

3. Clericuzio CL, Martin RA. Diagnostic criteria and tumor screening for individuals with isolated hemihyperplasia. Genetics in Medicine. 2009;11(3):220-222. doi:10.1097/GIM.0b013e31819436cf.

4. Goldman $\mathrm{M}^{1}$, Shuman C, Weksberg R, Rosenblum ND, Hypercalciuria in Beckwith-Wiedemann syndrome. J Pediatr. 2003 Feb;142(2):206-8. DOI:10.1067/mpd.2003.82. 